\title{
The Effect of Perceived Characteristics of DOI and Technology Adoption on SMEs Performance in Malaysia
}

\author{
Jaya Kumar Shanmugam, Teoh Ai Ping, Ramayah Thuraisamy
}

\begin{abstract}
This study aimed to investigate the impact of perceived characteristics on Diffusion of Innovation (DOI) and few other factors through information technology (IT) adoption on Small and Medium Enterprises (SMEs) performance. This paper summarized and synthesized relevant literature and mainly contributed to the Diffusion of Innovation theory. Other than the perceived characteristics of Diffusion of Innovation, the literature on organizational image, technology readiness, and organizational awareness were explored in relation to IT adoption to enhance SMEs performance. The outcome of this paper would inform especially on Malaysian researchers to further analyze the theory of Diffusion of Innovation on SME context. Organizational image, technology readiness, and organizational awareness are the eye opener for future researchers to explore more on these issues. It was proposed that, a questionnaire to be distribute among manufacturing SMEs in Malaysia and the data is analyze using Smart PLS. It is expected that the perceived characteristic of diffusion of innovation, organizational image, technology readiness, and organizational awareness are the factors to be considered in information technology adoption to enhance SMEs performance.
\end{abstract}

Keywords: Diffusion of Innovation, Information Technology Adoption, Performance, Small and Medium Enterprises.

\section{INTRODUCTION}

Small Medium Enterprises (SMEs) is an essential to the developing countries ${ }^{1}$. According to the World Bank, 600 million jobs are needed to fulfill the growing global workforce in the next 15 years. This estimation is made specifically for Asian and Sub-Saharan African countries. SMEs create four out of five new positions in emerging markets, particularly for formal jobs. In Malaysia only, there are $98.5 \%$ of business establishments which comprise SMEs. They contribute $33.1 \%$ of the gross domestic product (GDP) of the country, $57.5 \%$ of the nation's jobs, and $19 \%$ of the nation's exports. ${ }^{2}$. The government sets a target that the nation's GDP will rise up to $41 \%$ by $2020^{2}$.

Manuscript published on November 30, 2019.

* Correspondence Author

Jaya Kumar Shanmugam *, Graduate School of Business. Universiti Sains Malaysia.

Teoh Ai Ping, Graduate School of Business, Universiti Sains Malaysia.

Ramayah Thuraisamy, School of Management, Universiti Sains Malaysia.

(C) The Authors. Published by Blue Eyes Intelligence Engineering and Sciences Publication (BEIESP). This is an open access article under the CC-BY-NC-ND license http://creativecommons.org/licenses/by-nc-nd/4.0/
Most of SME owners are face difficulties in managing information technology (IT) in their organizations. There subject of concern here is that, if the SME owners were still not ready to adopt IT in their business organization, how would they be able to familiarize themselves with Industry 4.0. According to the Malaysian Minister of Entrepreneurship and Development, approximately $73 \%$ of SME owners in Malaysia are IT illiterate ${ }^{2}$. The SME owners are reluctant to learn IT and they do not realize the benefit and outcome of incorporating IT in their business organization. They should accept the reality that IT adoption would help increase the SMEs performance ${ }^{3}$. Furthermore, IT adoption would also enable them to create new opportunities and services for SMEs businesses. Since human errors are common and unavoidable, IT adoption would help reduce those errors in business transactions when they are computerized ${ }^{3}$ However, there are some constraints of adopting IT such lack of training on the use of information technology system, organizational characteristics, business strategy, owners' commitment and need of external IT expertise ${ }^{4}$. The economic globalization makes business more reliant on the IT usage. Therefore, SMEs need to be on track with IT development to get the updates and not being left behind. SMEs tend to lose the chances to enter into international supply chain and efficient production if important not given toward IT development ${ }^{5}$. Another threat for SMEs is IT adoption in large organizations ${ }^{6 .}$ Larger companies are highly advanced on IT adoption and they would utilize it to bring their businesses to the international level. Studies on Malaysian SMEs especially those that focus on information technology are still under-searched. Hence, a clear understanding on SMEs in Malaysia is important to address those issues.

\section{LITERATURE REVIEW}

\section{A. SMEs in Malaysia}

SMEs cannot be categorized as micro, small or medium based on size alone, but number of employees, sales revenue, turnover, total assets and net value need to be considered as well ${ }^{7}$. Some common measures used to define the size of SMEs are level of production, total assets, relative size within industry, number of employees, values of products, contribution to gross domestic product, and sales turnover ${ }^{8}$.

The total number of SMEs in Malaysia in $2016^{2}$ was 907,065 . 


\section{The Effect of Perceived Characteristics of DOI and Technology Adoption on SMEs Performance in Malaysia: A Conceptual Paper}

These were the active establishments of SMEs (consisting of micro, small and medium enterprises) out of the total 920,624 companies registered with the Companies Commission of Malaysia (CCM). The details are shown in Table I.

Table I: Number of Establishment of SMEs

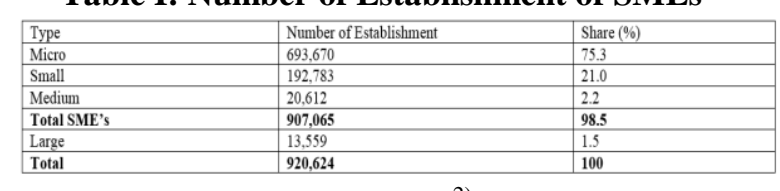

(Source: ${ }^{2)}$

\section{B. SME Performance}

Performance is key determinant to measure the success of SMEs 9. It may refer to the outcome received by the owners on the effort exerted to the firm ${ }^{9}$. In general, strong SMEs performance demonstrates business success as well as business growth. In the past years, SMEs were accounted for $33.1 \%$ of the country's GDP and created $57.5 \%$ of total job opportunity ${ }^{2}$. The details of GDP contribution over time from 2010 to 2017 are illustrated in Table II.

Table II: Contribution of SMEs to Overall GDP by Economic Sector (\%)

\begin{tabular}{|l|l|l|l|l|l|l|l|}
\hline $\begin{array}{l}\text { Sectors } \\
\text { Year }\end{array}$ & 2010 & 2011 & 2012 & 2013 & 2014 & 2015 & 2016 \\
\hline Agriculture & 4.3 & 4.3 & 4.1 & 4.0 & 4.5 & 4.3 & 4.1 \\
\hline Mining \& Quanrying & 0.0 & 0.0 & 0.1 & 0.1 & 0.1 & 0.2 & 0.2 \\
\hline Manufacturing & 7.2 & 7.4 & 7.4 & 7.5 & 7.8 & 7.9 & 7.9 \\
\hline Construction & 0.9 & 0.9 & 1.0 & 1.1 & 2.0 & 2.1 & 2.1 \\
\hline Services & 19.6 & 19.9 & 20.1 & 20.5 & 21.1 & 21.4 & 21.8 \\
\hline Plus: Import Duties & 0.2 & 0.3 & 0.3 & 0.3 & 0.4 & 0.5 & 0.5 \\
\hline \% of SMEs to orerall GDP & 32.2 & 32.8 & 33.0 & 33.5 & 35.9 & 36.3 & 36.6 \\
\hline
\end{tabular}

(Source: ${ }^{2)}$

In 2010 the overall SMEs GDP contribution was $32.2 \%$ and it recorded an increase to $37.1 \%$ in 2017 , hence the percentage of SMEs to overall GDP increases annually and this suggests that SMEs would continue to contribute to the country's GDP. Basically, the performance of SMEs reflects their productivity and the advanced development in business growth ${ }^{9}$. Factors that contribute to performance need to be examined for business development. Firm performance refers to how a business organization can be managed in an orderly and honest manner to meet the requirements and value of submissions to customers and shareholders ${ }^{10}$. A good performance measurement model is required to measure the SMEs performance. The performance measurement would help the management to keep track on and control how the company performs and meets the organizational objectives and goals. In addition, the performance measurement would indicate business survival in the foreseeable future and meet the expectation and needs of primary stakeholder such as customers, creditors and lenders.A number of studies on performance measurement issues were conducted by past researchers. Basically, business performance measurement can be classified into financial and non-financial indicators ${ }^{11}$. Financial indicators are a traditional performance measurement technique that uses measurement such as profit, return on investment, and sale. Financial indicators can be identified using the figures given in the financial statement. However, an analysis on business performance does not solely depend on the financial statement because it also requires consideration on qualitative characteristics. This may include customer satisfaction, employee needs, and wider community ${ }^{9}$. Moreover financial and non-financial indicators are important determinant for performance measurement to be measured ${ }^{12}$. There are five main financial indicators identified to measure business performance: profitability, cash flow position, return on investment, inventory turnover, and budget versus actual performance ${ }^{13,14,15,16}$. However, for the non-financial indicators, customer satisfaction, product/service quality, employee management, and working culture are the best measurement.

Apart from that, financial indicators also can be measured by net turnover, cash flow report, current ratio, asset turnover, accounts receivable turnover, inventory turnover, payable turnover, total debt ratio in the balance, debt-t-equity ratio, gross profitability, return on assets (ROA), return on equity (ROE), return on sale (ROS), return on investment (ROI), EBITDA profitability, and debt service coverage ratio (DSCR) ${ }^{17}$. While the non-financial indicators include level of consumer satisfaction, increase of number of consumer, consumer's loyalty, quality of products and services, motivated employees, loyal employees, level of employee's satisfaction, development of new products and services, training of new employees, company reputation and market share ${ }^{17}$. However, the financial performance also consists on structure of ownership such as number of shareholders, family ownership portion, managerial ownership portion, venture capital ownership portion, and board composition ${ }^{18}$. This measurement mainly focuses on firm equities, particularly the share portion. Business equity would determine the survival of the business in the foreseeable future. If the business has difficulty in the equity structure shift, then this would lead to business failure. Apart from that, ${ }^{19}$ explained that the good financial measurement for entrepreneurship are gross profitability, gross sales, stock turnover, total obligation ratio in the balance, EBITDA profitability, profit before tax, profit per employees and return on investments. Generally, there are numerous factors to be considered as measurement tools in assessing firm performance. Using financial and non-financial indicators are the most prominent measures to avoid any bias in data collection.

\section{Diffusion of Innovation (DOI)}

Diffusion of Innovation Theory (DOI) was originated by Roger in 1983. Roger stated that diffusion is the process of how innovation in communication spread to the community in social systems. Roger urged that DOI reveals the level of acceptance of new systems and adoption of new ideas, behaviour or products. Furthermore, adoption of new ideas, innovation and technology would only be successful if a person is perceived to adapt. DOI can be used to explain how new ideas of technology would migrate from the creator to be used in the future. There are five stages of communication channels in DOI; knowledge, persuasion, decision, implementation, and confirmation. Before the innovation takes place, an analysis on previous ideas, products or behavior must be conducted. Innovators must make a comparison between old ideas, products or behavior with the new ones to avoid unnecessary problems. Last but not least, the innovators need to understand the norms of social systems. This means that the acceptance level of innovation by the society would determine the success or failure of a new idea. In this study, a communication channel of DOI known as persuasion is explored since this would persuade SMEs to accept or reject the IT adoption. 
The next part reviews the literature on this communication channel. There are five perceived characteristics of persuasion communication channel on DOI and they are relative advantage, compatibility, complexity, trialability, and observability. The five perceived characteristics are measured as factors on IT adoption.

\section{Perceived Characteristics of Diffusion of Innovation (DOI)}

Relative advantage is directly influenced by computer-related adoption ${ }^{20}$. Users who previously practiced different tools or software in information technology always prefer to use similar adoption methods if new ideas were introduced to them. This indicates that they are reluctant or not yet ready to learn or adopt new ideas since they are already in their comfort zone $20,21,22$. Relative advantage has a significant influence towards internet-based information technology and communication adoption ${ }^{23,19}$. In different research, relative advantage positively influences SMEs to adopt enterprise systems because of lack of IT experts and also convenience to have similar type of systems in case the business organization proposes to supersede a new system ${ }^{24,} 25$

The next perceived characteristic is complexity. Complexity directly influences IT adoption in online marketing capabilities and business performance ${ }^{26}$. The SMEs owners find difficulties using websites, blog, and social media for marketing purposes. Normally the creative industry which involves in traditional fashion such as batik making is slightly poor in IT-based knowledge ${ }^{26}$, while complexity directly influences internet-based adoption ${ }^{19}$. The SMEs owners face intricacy incorporating internet into their business operation especially the elders who are reluctant to accept the changes. Complexity is positively significant on SMEs adoption of enterprise systems ${ }^{24}$. An implementation of one single system that uncovers all department transactions and issues would create difficulties for small-scale businesses. However, complexity could turn into a barrier in adoption decision ${ }^{27}$. A decision such as innovation implementation towards business could be affected by complexity factor. Once a decision is deemed difficult to be adopted, this idea then would be rejected. Complexity is also known as perceived easy usefulness and this would have a notable impact towards IT adoption intention ${ }^{28}$.

Next, trialability plays an important role in cloud-computing adoption ${ }^{20}$. Basically, cloud computing deals with network of remote server for internet, process data other than using local server or personal computer. Before the adoption of cloud computing, a trial version should be implemented. According to ${ }^{26}$, trialability towards ICT adoption on web-based application is essential. Web-based application into businesses does not always bring good signs because certain enterprises prefer to market their products offline. To avoid any potential loses, an experiment on web-based application needs to be conducted and if it brings benefits to the business organization, then only it may be considered to be applied. Trialability plays a significant role in internet-based ICT adoption ${ }^{23}$. SMEs businesses need to carry a trial version on ICT adoption using internet before it would be applied into the operations. In another context, trialability has a positive relationship with SMEs adoption of enterprise systems ${ }^{27}$. Generally, enterprise systems are costly because all systems (e.g. accounting information system, management information system, human resource system, and inventories system) are integrated into a single system ${ }^{27}$.

The next perceived characteristic is compatibility. Compatibility refers to making a comparison with the alternative choice to choose the best. Compatibility always influences IT adoption, primarily for costing and outcome towards performance ${ }^{21}$. The cost for implementing certain systems is highly expensive and because of that, it is necessary to make a comparison analysis with the similar systems. Compatibility has a significantly positive relationship with internet-based ICT adoption 19. Compatibility also positively influences enterprise systems adoption by SMEs ${ }^{24}$. Basically, enterprise systems adoption may not be suitable for all SMEs and in fact, the nature of businesses can also be a factor for it. For instance, a small-scale business with limited capital may find a difficulty to afford the full enterprise systems. Thus, a reasonable and detailed comparison needs to be conducted before IT is implemented to override the existing systems.

Observability, on the other hand, refers to the reflectiveness of new ideas or innovation which results from adopting innovation into business organizations. Observability also refers to the ability to see the benefits of innovation results. These benefits are seen before the adoption or even after the adoption of innovation. Some business owners may predict the return which is going to be earned by adopting IT to the business organizations. If there is no benefit of applying the IT innovation, they may reject the adoption decision ${ }^{19}$. Observability influences business performance in adopting emails and web-based applications (websites, blog, and social media) ${ }^{26}$. Fashion products by e-advertising can easily attract customers because its industry moves into the digital world. Social media such as Facebook and Twitter are a great tool for e-advertisement and they could bring a big success to the businesses ${ }^{26}$. Observability has a significant relationship with internet-based ICT adoption ${ }^{23}$, 19. Adopting ICT into business would always be beneficial to the owners even though the results would be portrayed at a later time. Observability plays an important role in SMEs adoption of enterprise systems ${ }^{21,24}$. An integrated system would make the business operation to be systematic with less errors rather than having various systems for each department.

However, observability does not have any significant effect on green fertilizer technology adoption ${ }^{29}$. This contradicts with the benefits that would be gained from the concept of go green. Most farmers with little education only think for the short term and would use traditional fertilizers (chemical-based). For example they might not be exposed to using green fertilizers such as urea and biomass. In fact, these green fertilizers are much lower in terms of cost and easier to be produced. Hence, they fail to observe business success in the future.

\section{E. Organizational Awareness, Technology Readiness and Organizational Image.}

The definition for organizational awareness is the understanding level and identification obtained by businesses when they have decided to adopt IT for their business operations ${ }^{30}$. Risks on IT adoption are reduced when the potential adopters have awareness on IT in different characteristics $^{31}$. 
Lack of awareness on the intention to adopt IT in different business operations would bring failure and the owners would blame that IT is less beneficial ${ }^{32,33}$. In the first place, they deem that basic knowledge or perception on IT such as the use of software and internet must be clearly understood. This is the most common mistake made by SMEs. Because awareness plays an important role in IT adoption, the benefits and advantages of IT usage need to be promoted among the potential adopters to create ${ }^{34,35}$. The adopters might refuse to adopt IT into their business organization if they are not aware on its benefits and advantages. They found that an investment on IT is a waste of resources.

Technology readiness is identified as the acceptance level of new technologies for personal benefit and to the firm ${ }^{36}$. This construct also refers to how people or organizations are ready to accept a challenge by implementing new technologies. Technology readiness is a key antecedent to determine the success of e-voting technology adoption ${ }^{37}$. Regardless of areas of study, technology readiness plays a significant role in the presence of technology adoption. Business organizations need to be ready physically on computer hardware, software, and internet. Not only it terms of the physical necessities, the skills and knowledge on IT must be sufficient too to overcome the challenges from difference angles. Sufficient skills and knowledge in technology should be nurtured to the people who handle any IT-related tasks. Owners' IT ability and technology readiness have a significant impact on e-commerce adoption ${ }^{38}$. The research examined a few factors from the context of technology, organization, environment, and individuals that gave an impact towards electronic business adoption. The findings of the study show that IT adoption solely depends on the organization itself and if the organization has yet ready for it, the thought of IT adoption then should be postponed.

The next construct is organizational image. This construct is used to measure the position of organization in a public view $^{39}$. Image plays an imperative role in IT adoption. People who adopt innovation for crave on getting a social status ${ }^{31}$. Most of the previous scholars found that image is not a good antecedent towards predators through IT adoption except few authors ${ }^{40}$. The authors discovered image seemed to have a constructive significant impact towards perceived ease of use, perceived usefulness, and behavioral intention in ICT acceptance. The study indicates that image is people's prestige on ICT adoption. The SMEs owners believe that in order to create a good image of their business organization among their competitors, IT adoption is the best solution ${ }^{40}$. Image is considered when the SMEs owners' intent to adopt IT since they understand better on the importance of IT rather than merely for self-prestige ${ }^{39}$. Only social influence has a strong effect towards e-government adoption 41,42,43,44. However, the result from the past studies cannot be generalized as the final outcome. This is because other factors such geographic and industry should be considered too in research.

\section{F. IT Adoption in SMEs}

IT expresses digital information and it covers the basic use of computer, offline and online, digital telecommunications, electronic media, wireless technology and various electronic apps such as e-banking, e-governance, and e-commerce ${ }^{45}$. IT adoption in SMEs helps minimize the cost by reducing the number of employees ${ }^{46}$. This is done by shortening the workload through the integration of all departments into one system, thus reducing the need for manpower.

External strain, information processing requirements, IT-enabled invention and performances, and competitiveness pressures considered as main factors to be considered before the IT adoption in SMEs ${ }^{47}$. A research is conducted to identify the relationship between IT adoption with the other five factors, namely perceived benefits, perceived cost, IT knowledge, outside pressure, and state authority support ${ }^{48}$ The findings of the study indicate that only perceived benefits, ICT knowledge, and government support contribute significantly towards the IT adoption among SMEs in Malaysia ${ }^{48}$. Perceived benefits and IT knowledge directly influence IT adoption in SMEs because these would improve SMEs performance. SMEs may use internet to promote their businesses worldwide and this would create a business opportunity for them. Furthermore, using emails as a communication tool with suppliers and customers brings efficiency and effectiveness into business process.

The level of awareness and IT adoption imply the patterns of IT adoption. If the correct factors or patterns of IT adoption are identified, policies would be able to be derived and the level of IT adoption developed ${ }^{46}$. IT adoption (transactions over internet) would help increase SMEs sales. The use of internet would help e-commerce in marketing the businesses worldwide and creating business opportunities ${ }^{50,51}$. On the other hand, turnover, industry, number of employee, business scale, and style are the factors towards IT adoption in SMEs. In line with previous research, IT adoption would help increase business productivity, communication, and opportunity to get new customers ${ }^{5,52,53,5455}$. It is suggested that SMEs should use personal computer (PC) with basic software to process business information and keep track on business record. They are some constraints on IT adoption in SMEs such as weak telecom infrastructure, lack of IT knowledge, unable to incorporate IT into enterprise, costly IT equipment, and poor government regulation on e-business ${ }^{56}$.

A quality information system support leads the SMEs to fight for new markets, products, and distribution channels 5,57 . The cost for buying new IT tools (computer and software) and communication network system is a main factor for the IT adoption in SMEs. In addition, SMEs face a big challenge when their initial set-up cost is high ${ }^{59,59,60}$. Small firms would have issues on financial resources and it would discourage SMEs to implement IT adoption ${ }^{61}$. An adequate IT infrastructure directly influences IT adoption in SMEs. A proper design in telecommunication equipment and service would increase the usage of IT in SMEs. Unfortunately, this factor also reflects on the cost of investment on IT. Next, government plays a vital role in IT implementation in SMEs 60,62 . Government support is significant and has a positive effect towards IT implementation. Some initiatives taken by the government might encourage the use of IT in the firm such as financial support, tax breaks, and technology infrastructure 63. Management support becomes one of the factors in IT adoption in SMEs ${ }^{5}$. The management would encourage the use of IT, provide reasonable trainings, and help enhance the IT knowledge and skills among the persons in charge. Senior executive support is also crucial in IT adoption in the firm because these people have the authority to make any decision towards business transformation ${ }^{64}$. 
Hence, they have the rights to change the tradition and modernize it by adopting IT and this would lead to business success and enhance business performance. There are three barriers in adopting IT in SMEs and they are external pressures, organizational readiness, and perceived benefits 65,66 . The trading partners require traditional methods on business transaction because they lack of ICT expertise and skills; this would stop the firm to use technology. Most of the CEOs and employees of SMEs accept and adopt the use of technology in business ${ }^{67}$. They also acknowledge the fact that the use of IT increases their profit margin as well as business performance. The CEOs and employees generally show great interest in the IT usage and are committed towards the adoption of technology and this would contribute positively to the whole process of business organization. However, most SMEs do not utilize technological tools in their business daily operations ${ }^{67}$.

IT infrastructure provides service and support to continue business operations ${ }^{68}$. This IT infrastructure is basically categorized into three components, namely hardware, software, and network. By using appropriate IT software, the business performance may be enhanced. Basic hardware such as computer, printer, scanner or cash register machine would be used in small businesses. The objectives of using these tools are to minimize workload and improve business operations operation. Software is no less spectacular compared to hardware. Lately, some businesses use several software in the business operation and this software are Management Information Systems (MIS), Accounting information Systems (AIS), Human Resource Management Systems, (HRM) and others. For instance, a business might use AIS for collection, storage, control, analysis, retrieval and disclosure of financial data which can also be used by the stakeholders like accountants, consultants, business analysts, directors, chief financial officer (CFO), auditors. and regulators, and inland revenue board for their decision-making process. Apart from that, computer network would also help in business activities and may expand them to the international level.

A positive relationship exists between IT infrastructure capability and organizational capability ${ }^{69,70}$. Basically, the government has more influence to implement IT adoption in business organization. The provision of government incentives is important to ensure that the implementation of IT into the businesses a success. This would help them in IT investment especially in developing countries including. However, these supports are not well utilized in some developed countries such as France, Germany, and the Netherlands $71,72,73$. Moreover, legal protection and government rule enforcement are also the channels to make the event a success ${ }^{74,75,76}$.

After review the past literature, a research framework is developed for further research as shown in the Figure I.

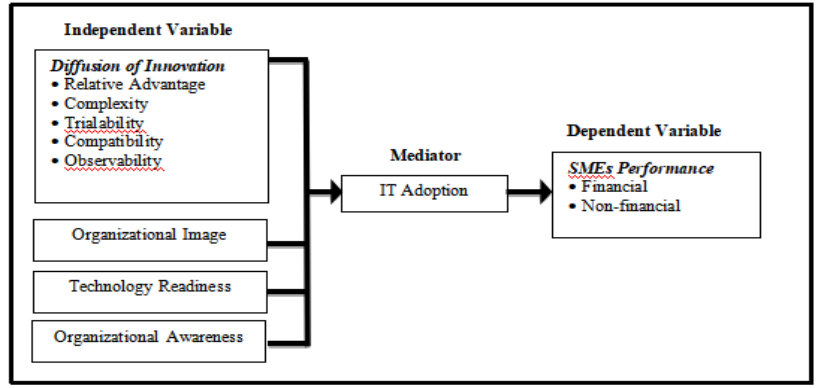

Figure I: Research Framework

\section{PROPOSED METHODOLOGY}

Table III shown total SMEs in specific corridors. In later part, the data to be analyze using Smart PLS.

Table III: Total SMEs in Specific Corridors

\begin{tabular}{|l|l|l|l|}
\hline Corridors & States & Total SMEs & $\begin{array}{l}\text { States } \\
\text { Selection }\end{array}$ \\
\hline \multirow{4}{*}{$\begin{array}{l}\text { Northern } \\
\text { Corridor }\end{array}$} & Perlis & 6,808 & \multirow{4}{*}{ Perak } \\
\cline { 2 - 3 } & Penang & 66,921 & \\
\cline { 2 - 3 } & Kedah & 48,894 & \\
\cline { 2 - 3 } & Perak & 75,140 & \multirow{4}{*}{ Kelantan } \\
\hline \multirow{3}{*}{$\begin{array}{l}\text { Eastern } \\
\text { Corridor }\end{array}$} & Kelantan & 46,618 & \\
\cline { 2 - 3 } & Terengganu & 29,324 & \multirow{3}{*}{ Sohor } \\
\cline { 2 - 3 } Couthern & Pahang & 37,573 & \\
\hline \multirow{3}{*}{$\begin{array}{l}\text { Central } \\
\text { Corridor }\end{array}$} & Melaka & 31,361 & \\
\cline { 2 - 3 } & Johor & 98,190 & \\
\cline { 2 - 3 } & Kuala & 133,703 & \\
\cline { 2 - 3 } & Selangor & 179,271 & \\
\cline { 2 - 3 } & Negeri & 32,721 & \\
\hline
\end{tabular}

(Source: Economic Census 2016, Profile of Small and Medium Enterprise, reference year 2015, Department of Statistics Malaysia)

\section{RESULT ANALYSIS}

A qualitative study will be conduct and a questionnaire is distributing among manufacturing SMEs in Malaysia. The unit of analysis for this study is the SMEs firm itself. The respondent detail is obtaining from Federal of Manufacturing Malaysia. Further, the data collection process is focus on four main corridors in Malaysia.

\section{CONCLUSION}

IT adoption plays an important role in SMEs performance. A list of studies to be completed to examine the effect of IT adoption towards SMEs performance. However, the concern that has been raised is the significance of IT adoption in enhancing SMEs performance. If there is no proper monitoring and control on IT adoption, the investment into this resource would be a failure and create competitive disadvantages. Hence, further studies could examine the ways of how to enhance this relationship. Since SMEs is considered a major contribution towards nation's GDP, any issues pertaining to SMEs need to be handled in a good manner. Diffusion of innovation's perceived characteristics through IT adoption plays an important role in SMEs performance. 


\section{The Effect of Perceived Characteristics of DOI and Technology Adoption on SMEs Performance in Malaysia: A Conceptual Paper}

A detailed literature on perceived characteristics of DOI, organizational image, technology readiness, organizational awareness, and IT adoption are critically discussed. A research framework is developed after examining the past literature. Perceived characteristics of DOI play an important role in the effectiveness of IT adoption and firms' performances. Performance measurement would help the management to keep track on and control business performance. Performance measurement is highly important as it would help the management to assess business survival in the foreseeable future. Additionally, it would meet the expectations and needs of stakeholders such as customers, creditors and lenders.

\section{ACKNOWLEDGMENT}

A special gratitude is expressed to the Malaysian Government since this study is partially sponsored under the Scheme of My Brain 15 Scholarship.

\section{REFERENCES}

1. The World Bank, 1 September 2016.http://www.worldbank.org/en/topic/financialsector/brief/smes-fin ance.

2. SME Annual Report 2016/2017. http://www.smecorp.gov.my/index.php/en/resources/2017-12 21-11-07-06/sme-annual-report/book/7/Array

3. Akande, O. O. (2015). Does Information Technology (IT) Influence Entrepreneurial Operations Efficiency: An Empirical Investigation of the Nigerian Small and Medium Businesses SMBs. IOSR Journal of Business and Management (IOSR-JBM) Volume 17, Issue 4.Ver. V, PP 19-24.

4. Budiarto, D. S. and Prabowo. (2015). Accounting Information System Alignment and Smes Performances: A Literature Review. International Journal of Management, Economics and Social Sciences, Vol. 4(2). Pp.58-70.

5. Irefin, I. A., Abdul Azeez, I. A. and Tijani, A.A. (2012). An Investigative Study of the Factors Affecting the Adoption of Information and Communication Technologies in Small and Medium Scale Enterprises in Nigeria. Australian Journal of Business and Management Research, Vol.2 No.02 (01-09).

6. Ndubisi, N. O. and Jantan. M. (1997). Evaluating IS Usage in Malaysian Small and Medium-Sized Firms Using the Technology Acceptance Model. Logistic Information Management, Volume 16-Number 6, Pp.440-450.

7. Ojo, A., Akinsunmi, S. and Olayanu, O. (2015). Influence of Business Philosophy and Practice (e-journal). Paper 1208.

8. Breen, H., Huultjens, J., \& Hing, N. (2005). Evaluating Implementation of a Voluntary Responsible Gambling Code in Queensland, Australia. International Journal of Mental Health \& Addiction, Vol. 3 No. 1, pp.15-25.

9. Hasan, F.S.M.A. and Almubarak, M.M.S. (2016). Factors Influence Women Entrepreneur's Performance in SMEs: World Journal of Entrepreneurship, Management and Sustainable Development Vol. 12 No. 2, 2016 Pp. 82-101.

10. Rashid, A. (2018). Board Independence and Firm Performance: Evidence from Bangladesh. Future Business Journal Vol4, Issue 1, pp 34-49.

11. Moorthy K.M., Annie T., Caroline C., Chang S. W., JonathanT. Y. P. \& Tan K. L. (2012). A Study on Factors Affecting the Performance of SMEs in Malaysia. International Journal of Academic Research in Business and Social Sciences, 2 (4), 224-239.

12. Kaplan, R.S. and Norton, D.P. (2000). The Strategy Focused Organization: How BalancedScorecard Companies Thrive in the New Business Environment: Harvard Business School Press, Boston,MA.

13. Neely, A. (1999). The Performance Measurement Revolution: Why Now and What Next? "International Journal of Operations \& Production Management, 77 University of Cambridge, UK: MCB University Press, Vol. 19, No. 2, Pp. 205-228.

14. Love, E. D., Irani, Z. and Edwards, D. J. (2004). Industry-centric Benchmarking of Information Technology Benefits, Cost and Risk for Information Use on Sales Performance of SMEs in Lagos State: Library

Small-to-medium sized Enterprises in Construction, Automation in Construction, 13(4), 507-524.

15. Matsumoto, K, Shivaswamy, M and Hoban, JP Jr (1995). "Security Analysts' Views of the Financial Ratios of Manufactories and Retails", Financial Practice and Education 5, 44-55.

16. Sun, J, and Li, H (2006). Data Mining Method for Listed Companies' Financial Distress Prediction, Knowledge-Based Systems, Uploaded On 8 December 2006

17. Kotane, I. (2015). Evaluating the importance of financial and non-financial indicators for the evaluation of company'sperformance Management Theory and Studies for Rural Business and Infrastructure Development. Vol. 37. No. 1: 8094.

18. Lappalainen, J. And Niskanen, M. (2012). Financial Performance of Smes: Impact of Ownership Structure and Board Composition. Management Research Review Vol. 35 No. 11, Pp. 1088-1108

19. Tan, K.S, Chong, S.C, Lin, B. and Eze, U.C. (2008). Internet-Based ICT Adoption: Evidence from Malaysian Smes, Industrial Management \& Data Systems, Vol. 109 No. 2, Pp. 224-244.

20. Ismaili, A.S., Mengxiang, L. He, Q. and Shen, J. (2016). Cloud Computing Adoption Determinants: An Anaylsis of Australian SMEs. PASIS.

21. Walfall, C.S. (2014). The Use and Adoption of Information Communication and Technologies (ICTs) by Jamaican Micro, Small and Medium Sized Enterprises (MSMEs). Thesis, Howard University.

22. Hashim, M. K. \& Abdullah, M. S. (1999). Working Paper in Rural Small and Medium Scale Industries in the Global Era: Critical Success Factors for SMEs in Malaysia: A Strategic Perspective. Malaysia.

23. Duckworth, R. (2014). Examining Relationships Between Perceived Characteristics of Innovation and Adoption Intentions of Small and Medium Enterprises. Thesis, Northcentral University.

24. Ramdani, B., Chevers, D. And Williams, D. A. (2013). Smes' Adoption of Enterprise Applications a Technology Organisation-Environment Model. Journal of Small Business and Enterprise Development Vol. 20 No. 4, Pp. 735-753.

25. Papagiannidis,S. and Alshamaila,Y. (2012). Cloud Computing Adoption by SMEs in the North East of England a Multi Perspective. Framework Journal of Enterprise Information Management Vol. 26 No 3, 2013 pp. 250-275.

26. Setiowati,R., Hartoyo Daryanto, H.K. and Arifin,B. (2015). The effects of ICT adoption on marketing capabilities and business performance of Indonesian SMEs in the fashion industry Journal of Business and Retail Management Research.

27. Alshamaila, Y. and Papagiannidis, S. (2012). Cloud Computing Adoption by Smes in The North East of England Multi-Perspective Framework. Journal of Enterprise Information Management Vol. 26 No. 3, Pp. 250-275.

28. Wu, S.P.J., Straub, D.W. And Liang, T.P. (2015). How Information Technology Governance Mechanisms and Strategic Alignment Influence Organizational Performance: Insights from A Matched Survey of Business and It Managers. Mis Quarterly Vol. 39 No. 2, Pp. 497-518

29. Mannan, S. And Nordin, S.M. (2017). Innovation Diffusion Attributes as Predictors to Adoption of Green Fertilizer Technology Among Paddy Farmers in Perak State. Global Business and Management Research: An International Journal Vol. 9, No. 1s

30. Meftah, M., Gharleghi, B., \& Samadi, B. (2015). Adoption of E-Government among Bahraini Citizens. Asian Social Science, 11(4), 141-149.

31. Rogers, E.M. (1983). Diffusion of Innovations (3rd Ed.). New York: The Free Press.

32. Dewa, M., \& Zlotnikova, I. (2014). Citizens' Readiness for e-Government Services in Tanzania. Advances in Computer Science: An International Journal, 3(4), 37-45.

33. Mashau, N. L. (2016). Issues Affecting the Adoption and Usage of Mobile Instant Messaging in Semi-Rural Public Schools of South Africa for Learning. Open Access Library Journal, 3(11), 1-13.

34. Alshehri, M., \& Drew, S. (2010). Challenges of e-Government Services Adoption in Saudi Arabia from an e-Ready.

35. Hoque, M. R., Saif, A. N. M., Albar, A.M. and Bao, Y. (2016). Adoption of information and communication technology for development. A case study of small and medium enterprises in Bangladesh. Information Development, Vol 32, Issue 4, pp. 986 - 1000

36. Parasuraman, A. (2000). Technology Readiness Index (TRI) A Multiple-Item Scale to Measure Readiness to Embrace New Technologies. Journal of Service Research, Volume 2, No. 4, May 307-320. 
37. Salimonu, I.R., Shiek Osman, W.R. and Shittu, J.K. (2014). Modeling the Influence of Information Technology (IT) Adoption Factors on the Electronic Voting (E-Voting) Technology Using Partial Least Squares-Structural Equation Model (PLS-SEM) Methods. African Journal of Computing\& ICT, Vol 7. No. 2 - June.

38. Rahayu, R. and Day, J. (2015). Determinant Factors of E-commerce Adoption by SMEs in Developing Country: Evidence from Indonesia. Procedia - Social and Behavioral Sciences 195 (2015) $142-150$

39. Moore, G. C. and Benbasat. I. (1991). Development of an Instrument to Measures the Perceptions of Adopting an Information Technology Innovation. Information Systems Research 2(3), 192-221.

40. Azam, M.S., Quaddus, M. and Lubna, N. (2013). Behavioral Modeling of the Individual's Acceptance and use of Internet in Bangladesh: An Analysis Using an Integrated Approach. Journal of International Technology and Information Management, Volume 22 Issue 1.

41. Komba, M.M. (2016). Adoption of E-Government Services among Citizens in the Selected Districts of Tanzania. International Journal of Computer Science and Technology, Vol. 7, Issue 3, July - Sept.

42. Rokhman, A. (2011). E-Government Adoption in Developing Countries; the Case of Indonesia. Journal of Emerging Trends in Computing and Information Sciences, Volume 2 No.5, May.

43. Chatzoglou, P., Chatzoudes, D, and Symeonidis, S. (2015). Factors affecting the intention to use e-Government services. Proceedings of the Federated Conference on Computer Science and Information Systems pp. 1489-1498, Vol.5.

44. Catter, L. and Belanger, F. (2003). The Influence of Perceived Characteristics of Innovating on e-Government Adoption. Electronic Journal of e-Government Volume 2 Issue 1 (11-20).

45. Oluwataya, B. I. (Nd). Information and Communication Technologies as Drivers of Growth: Experience from Selected Small-Scale Business in Rural Southwest Nigeria.

46. Olise, M. C., Anigbogu, T. U., Edoko, T. U. and Okoli, M. I. (2014). Determinant of ICT Adoption for Improved SMEs Performances in Anambra State, Nigeria.

47. Ghobakhloo, M., Sabouri, M. S., Hong, T. S. and Zulkifli, N. (2011). Information Technology Adoption in Small and Medium-Sized Enterprises; an Appraisal of Two Decades Literature. Interdisciplinary Journal of Research in Business Vol.1, Issue. Seven, July 2011 (Pp.53-80).

48. Alam, S.S. and Noor, M K.M. (2009). ICT Adoption in Small and Medium Enterprises: An Empirical Evidence of Service Sectors in Malaysia. Int. J. Bus. Management, 4, 112-125.

49. Taylor, M.and A.Murphy (2004). SMEs and e- business. J. Small Busines Enterprise Dev, 11: 280-289.

50. Martin L.L and Matlay H. (2001) 'Blanket Approaches to Promoting ICT in Small Firms: Some Lessons From The DTI Ladder Adoption Model In The UK', Internet Research Vol:11 (5), Pp.399-410.

51. Ashrafi, R. and Murtaza, M. (2008). Use and Impact of ICT on Smes in Oman. Electronic Journal of Information Systems Evaluation, 11(3), 125-138.

52. Brynjolfsson, E. and Hitt, L. (1996). Paradox Lost. Firm-Level Evidence on the Returns to information Systems Spending. Management Science, 42(4)

53. Baldwin, J.R., Jarmin, R.S. and Tang, J. (2001). The Trend to Smaller Producers in Manufacturing in Canada and the US, Statistics Canada Working paper.

54. Ritchie, B. \& Brindley, C. (2000). Disintermediation, Disintegration and Risk in the SME Global Supply Chain. Management Decision, 38(8), 575-583.

55. Lucey, T. (2005): Management Information Systems, 9th Edition, London.

56. Kapurubandara, M., and Lawson, R. (2006). "Barriers Adopting ICT and E-commerce with SMEs in Developing Countries: An Exploratory Study in Sri Lanka”, Collecter'06, 9 December 2006.

57. Dixon, T., Thompson, B. \& McAllister, P. (2012). The Value of ICT for Smes in the UK: A Critical Literature Review, Report for Small Business Service Research Programme, the College of Estate Management.

58. Paul, D., \& Pascale, D. (2013). Information Technology and Economic Development: An Introduction to the Research Issues. Research Paper. Los Angeles, CA: Sage.

59. Matlay, H. and Westhead, P. (2013). Virtual Teams and the Rise of E-Entrepreneurship in Europe. International Small Business Journal, 23(3), 279-300.

60. Dutta, S. and Coury, M, E. (2003). "ICT Challenges for the Arab World", Chapter 8, in Dutta, S.

61. Thong, J. and Yap, C. (2001). CEO Characteristics, Organizational Characteristics and Information Technology Adoption in Small Business. International Journal of Management Science, 23(4), 429-442.

62. Sakai, K. (2013). Enhancing Manufacturing Performance with ERP Systems. Information Systems Management, 17(3), 1-13.

63. Alila, O., \& Ove, P. (2011). Negotiating Social Space: East African Micro Enterprises. African World Press.

64. Mabert, V. A., Soni, A. and Venkataramanan, M. A. (2006). Model Based Interpretation of Survey Data: A Case Study of Enterprise Resource Planning Implementations, Mathematical and Computer Modeling, 44, 16-29.

65. Mingaine, L. (2013). Challenges Encountered by Principals during Implementation of ICT in Public Secondary Schools, Kenya. Journal of Sociological Research, 4(2) $1-19$.

66. Ardjouman, D. (2014). Factors Influencing Small and Medium Enterprises (Smes) In Adoption and Use of Technology in Cote d'Ivoire. International Journal of Business and Management, Vol. 9, No. 8.

67. Weill, P., and Vitale, M. (2002). "What IT Infrastructure capabilities are needed to implement e-business models?" MIS Quarterly Executive (1:1), pp 17-34.

68. Baron, R.M., and Kenny, D.A. (1986). "The moderator-mediator variable distinction in social psychological research: Conceptual, strategic, and statistical considerations." Journal of Personality and Social Psychology, pp 1173-1182.

69. Sobel, M.E. (1982). "Asymptotic confidence intervals for indirect effects in structural equations models," in: Sociological Methodology, S. Leinhart (ed.), Jossey-Bass, San Francisco, pp. 290-312.

Published By:

Blue Eyes Intelligence Engineering and Sciences Publication (BEIESP) (C) Copyright: All rights reserved.
0. Bharadwaj, A.S., Sambamurthy, V., and Zmud, R. W. (2002). "Firmwide IT Capability: An Empirical Examination of the Construct and its Links to Performance," in: Working Paper.

71. Koenig, W., Wigand, R. T. and Beck, R. (2002) 'Globaliza- tion of E-commerce: Environment and Policy in Germany,' Center for Research on Information Technology and Organizations, University of California, Irvine, Irvine, CA.

72. OECD (Organization for Economic Cooperation andDevelopment) (1999) The Economic and Social Impact of Electronic Commerce, Paris: OECD.

73. Sadowski, B. M., Maitland, C. and van Dongen, J. (2002) 'Strategic Use of the Internet by Small- and Medium-sized Companies: An Exploratory Study', information Economics and Policy 14: 75-93.

74. Gibbs, J., Kraemer, K. L. and Dedrick, J. (2003) 'Environment and Policy Factors Shaping Global E-commerce Diffusion: A Cross-country Comparison’, The Information Society 19(1): 5-18.

5. Shanmugam, L., Yassin, S. F. \& Khalid, F. 2019a. Incorporating the Elements of Computational Thinking into the Mobile Application Development Life Cycle ( MADLC ) Model (5): 815-824.

76. Shanmugam, L., Yassin, S. F. \& Khalid, F. 2019b. Enhancing Students' Motivation to Learn Computational Thinking through Mobile Application Development Module ( M-CT ) (5): 1293-1303.

\section{AUTHORS PROFILE}

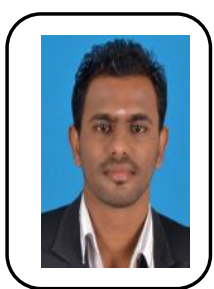

Jaya Kumar Shanmugam currently serves as Senior Lecturer cum Program Leader at SEGi College Penang. He has obtained his Bachelor of Accounting (Hons) and MSc. (Accounting) from Universiti Malaysia Terengganu. He has published a number articles on governance, firm performances and technology advancements. Recently he has obtained his membership on professional accounting body MIA in 2019. He is also providing freelance accounting and business consultation services.

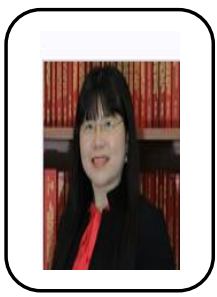

Teoh Ai Ping is a senior lecturer at University Sains Malaysia. She has obtained Bachelor of Accounting (Hons), MSc. (Information Technology) and Doctorate of Business Administration. She has published a numbers of articles and her research interests are on enterprise risk management, firm performances, business intelligence, and e-business. She has obtained a few memberships such MIA, IIAM, RIMS, IEEE and ACM.

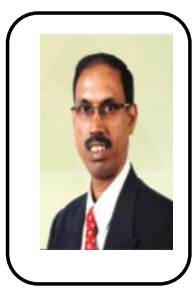

Ramayah Thuraisamay is a Professor at Universiti Sains Malaysia. He has obtained Bachelor of Management (Hons). He has published more than 500 articles with high index. His research interests are on scale development and validation, technology management, quantitative research and structural equation modeling $\mathrm{He}$ also providing consultations services to Tesco, Jusco, World Fish, Mimos, $\mathrm{MOH}$, TORAY. 